\title{
The Relation of Maxim Flouting Used to Illocutionary Function of Politeness in 12 Years a Slave Movie
}

\author{
Zain Nabilah Anjani \\ Balikpapan University \\ azainnabilah@gmail.com \\ Jepri \\ Balikpapan University \\ jeprinainggolan@gmail.com

\section{Siti Hafsah} \\ Balikpapan University \\ siti.hafsah@uniba-bpn.ac.id
}

\begin{abstract}
:
This thesis explores types of maxim flouting in 12 Years A Slave's Movie. There are two objectives of this research; 1) to identify the types of maxim flouting performed by Solomon Northup in 12 Years A Slave movie and 2) to seek out the relation of maxim flouting to the illocutionary function of politeness. The theories used in this research are the sociolinguistic analysis using Geoffrey Leech's theory of illocutionary function and the pragmatic analysis using H. P. Grice's theory of maxim flouting; the methodology employed is qualitative research in which the researcher tries to present the issues descriptively. As for the data, they were collected from the transcription of the movie script. The movie scripts were taken out as the primary data. This result of the research, the researcher found that (1) four types of maxim flouting performed by Solomon Northup: quantity, quality, relevance, and manner maxim flouting. (2) the relation of maxim flouting to the illocutionary function of politeness, divide into four reasons that lead Solomon Northup to flout the maxims are competitive, collaborative, convivial, and conflictive.
\end{abstract}

Keywords: maxim flouting, illocutionary function, politeness, 12 years a slave 


\section{INTRODUCTION}

Literature is a window of how people see their life even literature can be a mirror to somebody. Literature is very close to human's life and it was born from human's adaption, life, carrier, love, and emotions. There are many ways to express imagination and literature makes it concrete. In the high-tech era, advance technology makes the literature can be perceived through moving picture which is called movie.

Movie is one of kind a literary work creating good audio as well as visual. There is a huge change in term of literature, from written work to visualisation. Language cannot be separated from human life since it is a means of communication. Chaika states "Language and society are so intertwined that it is impossible to understand one without the other."

The action which is performed when an utterance is produced can be analysed into three different levels, namely locutionary acts, illocutionary acts, and perlocutionary acts . In this research, the level of speech acts which analyzed more is the illocutionary acts. Politeness is defined as the phenomenon which describes the way someone puts something as the result of a speaker's cognitive assessment of the social context. Being polite here can be shown by speaking in a positive way in order to make the conversation runs smoothly. Politeness itself is studied under the scope of sociolinguistics and pragmatics study. Everyone indeed has the possibility to flout the maxim of the Cooperative Principle. Then, it can be assumed that whether the conversation is in real life or even in a movie or in a novel that the script is made by people, maxim flouting can happen. Observing maxims means that a speaker fulfills the maxims to be cooperative in the conversation.

On the other hand, non-observing maxims suppose that a speaker fails in fulfilling the maxims of the Cooperative Principle. Maxim flouting belongs to non-observing maxims, among maxim violation, maxim opt-out, maxim infringement, and maxim suspension.

\section{LITERATURE REVIEW}

There are some hidden meanings and certain purposes that is tried to be conveyed by the speaker. In order that, in this part the researcher would like to explain the theory to answer the research question. The equivalent goal in the sociology of language development to discover a social structure can be better understood through the study of language and language features present to characterise particular social arrangements. Illocutionary act is a kind of speech acts which performs an act of doing something.

The speaker will utter their intention to do some action to the interlocutor. According to Searle, illocutionary acts perform the acts of doing something. Speakers may communicate their intention to do something by speaking the words. Politeness Politeness is defined as the phenomenon which describes the way someone puts something as the result of speaker's cognitive assessment of the social context.

Being polite here can be shown by speaking in a positive way in order to make the conversation runs smoothly. The Role of Politeness in Sociolinguistics Sociolinguistics is explained as the study of the relationship between language and society. Politeness belongs 
to sociolinguistics study since it focuses on the way language is used differently in a certain society. The study of politeness will be more related to a search for its markers in everyday conversations.

The Role of Politeness in Pragmatics Leech states that pragmatics deals with the meaning which is defined to be connected with a speaker of the language. Moreover, Leech defines pragmatics as "the study of meaning in relation to speech situations. In pragmatics' theory, language cannot be separated from context and principles of language use . Therefore, pragmatics focuses on how language is used by people in a certain context or situation.

This study can also be stated as pragmatics study because it analyses the language use and its meaning in relation to a speech context or situation. People must consider their language use according to the social context of the conversation so that their utterances will be considered as polite. The context in pragmatics may cause people to speak explicitly and/or implicitly. When people speak implicitly, they will talk about their intention indirectly.

According to Leech, the more indirect the statement is, the more polite it will be. Cooperative Principle Cooperative Principle is the basic principle in pragmatics in which people are demanded to make their conversation as cooperative as possible, in line with the purpose of the conversation. In this principle, there are four sub-principles called maxims which provide more detailed principles of conversational cooperation.

\section{Maxim Flouting}

\section{Quantity Maxim Flouting}

Quantity maxim flouting means that the speakers of a conversation fail to fulfil the maxim of quantity in the Cooperative Principle.

\section{Quality Maxim Flouting}

When a speaker flouts a maxim of quality, the speaker simply says something that does not represent what he or she actually thinks.

3. Relevance Maxim Flouting

Relevance maxim flouting means that the speakers of a conversation fail to be relevant in communicating.

4. Manner Maxim Flouting

To be clear in saying things is what all speakers try to do. However, in some occasion, ambiguity indeed happens whether the speaker intends to make it or not. Then, maxim of manner is not fulfilled as the result.

\section{Reasons for Maxim Flouting}

By flouting the maxims of Cooperative Principle, speakers intend to deliver an unstated meaning to the listeners. Those are the functions of saying something with some hidden 
meanings in order to act politely in front of the others. Those functions are somehow related to the reasons people flout the maxims of Cooperative Principles.

\section{Competitive}

This reason relates to the illocutionary goal that competes with the social goal as in ordering, asking, demanding, and begging (Leech, 1983, p.104).

\section{Convivial}

This is a reason for maxim flouting where an illocutionary goal coincides with the social goal as in offering, inviting, greeting, thanking, and congratulating (Leech, 1983, p.104).

\section{Collaborative}

Leech (1983, p.104) explains that collaborative happens when an illocutionary goal is indifferent to the social goal. There are asserting, reporting, announcing, and instructing that are included in this reason.

\section{Conflictive}

The last reason is conflictive reason. It is a reason where the illocutionary goal of a conversation conflicts with the social goal (Leech, 1983, p.104).

In flouting the maxims, people are intentionally breaking the rules of Cooperative Principle to convey unstated meaning. People have possibilities to flout one or more maxims of Cooperative Principle. Grice's theory of maxim flouting is used to answer the first objective of this research. According to Grice, there are four types of maxim flouting: quantity, quality, relevance, and manner maxim flouting.

For some cases, the speakers' implied meanings reflect the reason for maxim flouting. To answer the objective of identifying the reasons for maxim flouting, Leech's theory of Illocutionary Function is used.

\section{Previous Studies}

The researcher finds one of all works using 12 Years a Slave movie and two of works using the same approach but different discusses.

\section{A Study by Bagus Ardian Hakim}

The research by Bagus Ardian Hakim as the student of State Islamic University Sunan Kalijaga with entitled Human Right Violations in 12 Years a Slave. In Bagus' thesis has the same object with the researcher but different topic. The object 12 Years a Slave movie is same object with the researcher, but Bagus uses the new criticism theory "close reading" approach, he discusses about human rights violations while the researcher describes about maxim flouting. New criticism claimed that the text, as a complete work of art, is adequate for interpretation, and one should look at the text, and only the text. In order to analyse it and get the true meaning of it. The main objective of this study is to determine the purpose of 12 Years a Slave through the story of Solomon Northup in the film.

2. A Study by Fitria Nurhayati 
Fitria Nurhayati is one of the researchers focusing on the maxim flouting as her object of study. Her thesis entitled A Pragmatic Analysis of Maxim Flouting Reflected in the Oprah Winfrey Show in the Exclusive Interview with J. K. Rowling aims to describe the types of maxim flouting in the talk show. She argues that the most common reason for flouting maxims of Cooperative Principle is to be polite to the others. Therefore, in her thesis, the analysis is about maxim flouting and politeness principle while the researcher describes about maxim flouting use to illocutionary function of politeness. Fitria finds three types of maxim flouting, the researcher found four types of maxim flouting.

3. A Study by Nabilah Fairy Al-Bantany

Al-Bantany (2013) conducted a research entitled The use of commissive speech acts and its politeness implication: A case of Banten gubernatorial candidate debate. The purpose of this research was to examine the use of commissive speech acts in the debate and the realisation of politeness in the use of speech acts while the researcher describes about illocutionary function of politeness. This study was a qualitative study which processed the data gathered by downloading the debate. The data were analysed using the theory of speech acts by Searle and the theory of politeness by Brown and Levinson . The result of this research showed that commissive speech acts appeared in the debate for 53\% of the utterances.

\section{Synopsis}

12 Years a Slave is a 2013 historical drama movie about slavery. It is an adaptation of the memoir of Solomon Northup, a black freeman who is kidnapped and forced to be a slave. It is a story of Solomon Northup playing his role as a slave for 12 years, from 1841 to 1853, until he was able to contact his friend. This movie is based on a true story. It is directed by Steve McQueen and the adapted screenplay is written by John Ridley. It is starring Chiwetel Ejiofor as Solomon Northup, the main character.

\section{Director's Biography}

Steven Rodney McQueen CBE (born 9 October 1969) is a British film director and screenwriter. For his 2013 film, 12 Years a Slave, a historical drama adaptation of an 1853 slave narrative memoir. McQueen is the first black filmmaker to win an Academy Award for Best Picture. The film won the Academy Award for Best Picture in March 2014, becoming the first Best Picture winner to have a black director or producer. For his artwork, McQueen has received the Turner Prize, the highest award given to a British visual artist. "In April 2014, TIME magazine included McQueen in its annual TIME 100 as one of the "Most Influential People in the World.

\section{FINDINGS}

This section provides the data that have been obtained by the researcher to answer the objectives of the research. His life as a slave for 12 years has affected the form of his maxim flouting. The data are analysed descriptively by using Grice theory. The researcher found all of four types of maxim flouting in 12 Years a Slave's movie. 
Prologue: Journal on Language and Literature Vol.6 No.1 (2020)

\section{Maxim Flouting Used to Illocutionary Function of Politeness}

Diagram 1: Types of Maxim Flouting Relate to Illocutionary Function of Politeness

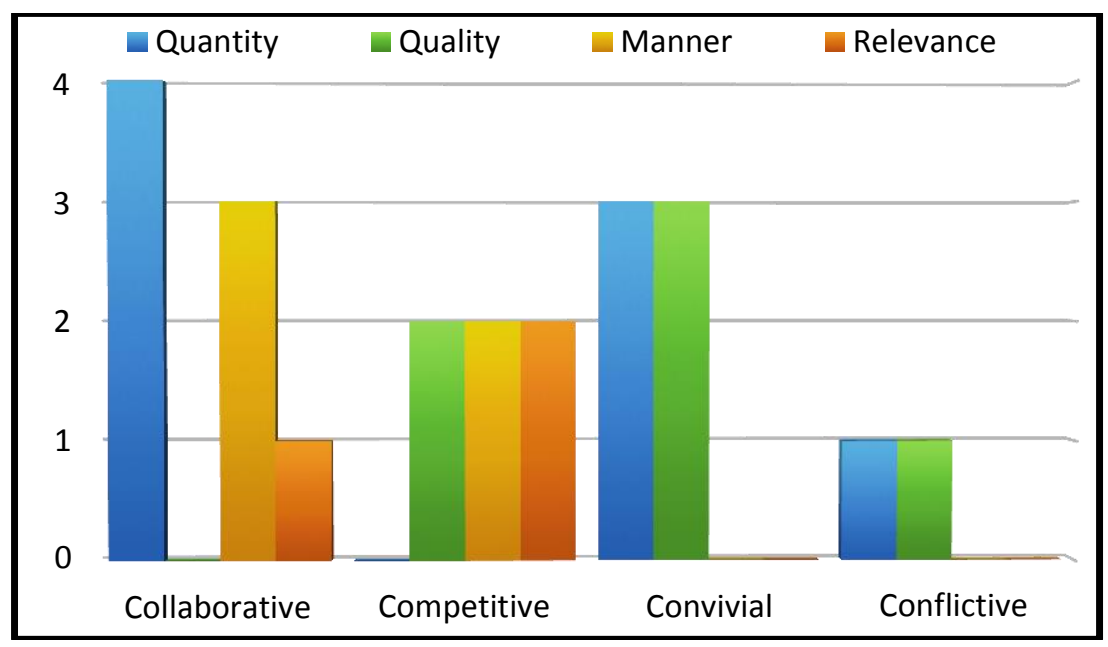

From the chart above, the reasons for maxim flouting are fairly various. The use of this reason is arising from the fact that Northup is a freeman forced to be a slave. His illocutionary goal must be struggling to regain his freedom no matter what. However, the social goal is expecting Northup to accept to live as a slave peace.

\section{DISCUSSION}

This section provides the explanation of data that have been obtained by the researcher to answer the second objectives of the research. The data are analysed descriptively by using Grice and Leech theory as the researcher explained before about types of maxim flouting features and the researcher gets the relation used to illocutionary function of politeness.

\section{Types of Maxim Flouting}

\section{Quantity of Maxim Flouting}

The first example in which Northup flouts maxim of quantity is taken from the following dialog. Jasper does not have a chance to respond to him. Northup has been more informative than is required. 'Mind your wallet' is an expression that is not really needed in his greeting. 


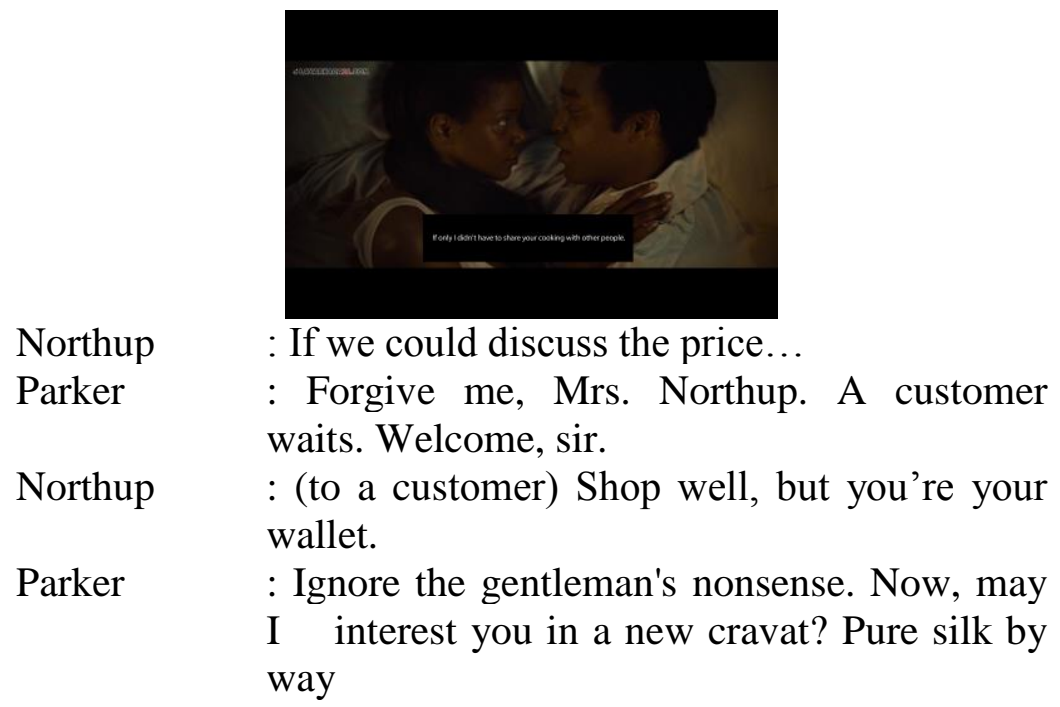

Saying this expression makes him fail in obeying the maxim of Cooperative Principle. His contribution is more than that is required in the exchange so he has done quantity maxim flouting of convivial reason. He breaks the maxim in which making a more informative contribution than is required is forbidden.

2. Quality of Maxim Flouting

He is deliberately saying something that lacks adequate evidence. Here, the matter of sharing cooking sounds bigger than the fact. He actually tries to say that the money is good as long as it is used correctly. Besides, he asks Anne to be loyal to him as in the case she will cook only for Northup.

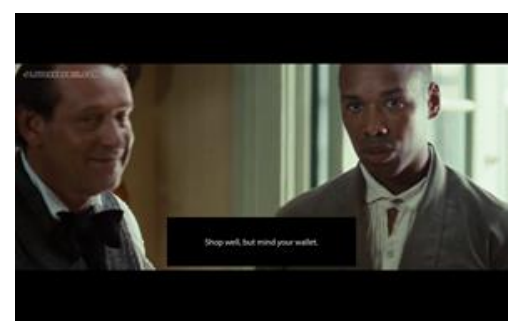

$\begin{array}{ll}\text { Northup } & \text { : I won't stay idle } \\ \text { Anne } & \text { : Darling, it's good money. } \\ \text { Northup } & \text { : If only I didn't have to share your cooking } \\ & \text { with other people. } \\ \text { Anne } & \text { : You don't. }\end{array}$

The statement as in the dialog does not mean literally that the money is bad or something if Anne shares her cooking with other people. It just indicates that Northup advises Anne to use the money wisely. Northup uses maxim flouting to deliver his massage. In this case, the maxim flouting belongs to quality maxim flouting since Northup does not make a reliable contribution and lack of adequate facts. 
3. Manner of Maxim Flouting

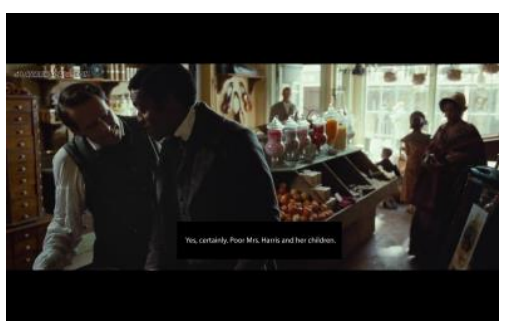

Parker : If you would sign our condolence book. My hope is to find a way to forward it to the Widow Harrison. Sad days for the nation.

Northup : Yes, certainly. Poor Mrs. Harris and her children. I hope brighter times ahead.

In this conversation, Mr. Parker asks Northup to sign the condolence book of the deceased President of the nation, William Henry Harrison. Agreeing the offer, Northup flouts maxim of manner by saying something which is ambiguous. It may be interpreted differently by the listener, Parker in this case.

4. Relevance of Maxim Flouting

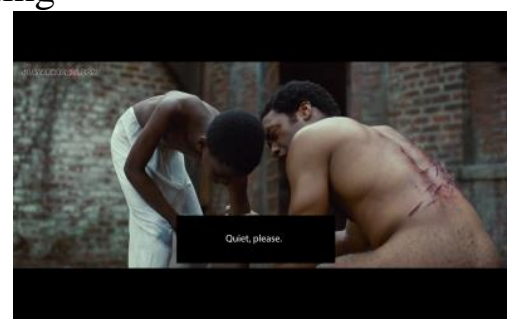

$\begin{array}{ll}\text { Randall } & \text { : Do you know when my Mama will come? } \\ \text { Radburn } & \text { : Hush him up! } \\ \text { Randall } & \text { : Mama ..! Mama! Is she going to come? } \\ \text { Northup } & \text { : Quiet, please. }\end{array}$

Maxim Flouting Used to Illocutionary Function of Politeness

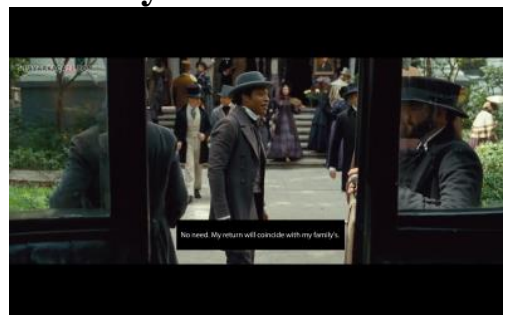

Hamilton : No letter to post?

Northup : No need. My return will coincide with my family's.

Brown : We're off then.

1. Collaborative Reason

Explaining about his return is actually not required for responding to Hamilton's question. Here, it can be seen that Northup tries to convey his intended meaning through maxim 
flouting. In this exchange, Northup's illocutionary goal is to convince Hamilton that no letter is okay. Then, the social goal is just to answer the other's question properly.

The illocutionary goal may collaborate with the social goal to achieve something. His answer becomes the means of convincing Hamilton. Since the illocutionary goal is indifferent to the social goal, maxim flouting happens in this conversation. This state is what is called as collaborative reason leading to maxim flouting.

Explaining about his return is actually not required for responding to Hamilton's question. Here, it can be seen that Northup tries to convey his intended meaning through maxim flouting. In this exchange, Northup's illocutionary goal is to convince Hamilton that no letter is okay. Then, the social goal is just to answer the other's question properly.

The illocutionary goal may collaborate with the social goal to achieve something. His answer becomes the means of convincing Hamilton. Since the illocutionary goal is indifferent to the social goal, maxim flouting happens in this conversation. This state is what is called as collaborative reason leading to maxim flouting.

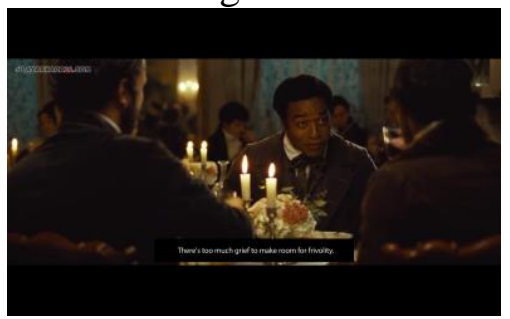

Brown : And not satisfied a bit despite giving them more than what they paid for.

Northup : It's the national mood. There's too much grief to make room for frivolity.

\section{Convivial Reason}

His illocutionary goal is to act wisely and the social goal is to calm the others. In conclusion, the reason for maxim flouting is a convivial reason in which Northup tries to diminish his disappointment and bring happiness to the others.

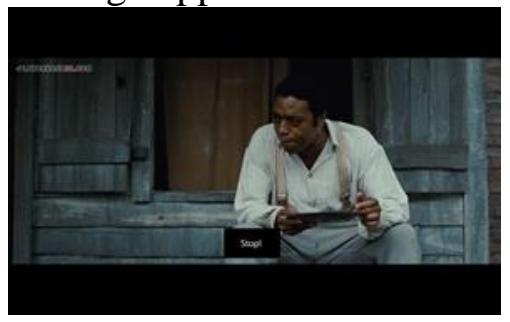

Northup : Eliza. Eliza, stop! Stop it! Stop!

Eliza : It's all I have to keeps my loss present.

Northup : You let yourself be overcome by sorrow. You will drown in it.

Eliza : Have you stopped crying for your children? You make no sounds, but will you ever let them go in your heart? 
3. Competitive Reason

\section{Conflictive Reason}

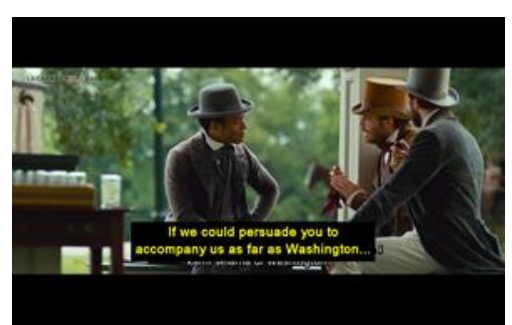

Brown : If we could persuade you to accompany us as far as New York... We would give you one dollar for each day's service and three dollars for every night played at our performances. In addition we would provide sufficient pay for the expenses of your return from New York here to Saratoga.

Northup : You understand this is all very sudden.

Saying the statement above, Northup tries to win his illocutionary goal by using maxim flouting. He presumes that Hamilton and Brown not give him enough time to consider the offer. The objectives of this research have been completely answered by using scenes, conversations, and explanation. The relationship between the two objectives has also been presented in the discussion. Hopefully, this chapter can provide an in-depth understanding in regard to the occurrences of maxim flouting used to illocutionary function of politeness.

\section{CONCLUSION}

Maxim flouting is used to illocutionary function function of politeness dominated by collaborative function particularly in quantity of collaborative. In other expression the collaborative function of quantity are expressed to show politeness. Being forced to be slave, there are some times when he gives too much information to reveal his true identity and too little information to act his role as a slave properly. In general, quantity maxim flouting is frequently used to convince another participant of the conversation.

\section{References}

Al-Bantany, N.F. (2013). The use of commissive speech acts and its politeness implication: A case of Banten gubernatorial candidate debate [Electronic version]. UPI e-journal passage, 1(2), 21-34.

Chaika, E. (1982). Language: The Social Mirror. Boston: Newbury House Publisher.

Grice, H. P. 1975. Logic and Conversation. Syntax and Semantic 3: Speech Acts, 3, 41-58. http://www.ucl.ac.uk/ls/studypacks/Grice-Logic.pdf. Accessed on 8 October 2018.

Hakim, B. A. (2015). Human Right Violations in 12 Years a Slave (online journal), http://digilib.uin- 
Prologue: Journal on Language and Literature Vol.6 No.1 (2020)

suka.ac.id/15560/1/BAB\%20I\%2C\%20IV\%2C\%20DAFTAR\%20PUSTAKA.pdf. Accessed on 13 March 2019.

Leech, G. (1983). Principles of Pragmatics. London: Longman Inc.

Nurhayati, F. 2012. A Pragmatic Analysis of Maxim Flouting Reflected in the Oprah Winfrey Show in the Exclusive Interview with J. K. Rowling, http://journal.student.uny.ac.id/jurnal/artikel/1128/40/203. Accessed on 10 December 2018.

Searle, J.R. (1969). Speech acts: An Essay in the Philosophy of Language. Cambridge: Cambridge University Press. 